\title{
The usefulness of perioperative lactate blood levels in patients undergoing heart valve surgery
}

\author{
Piotr Duchnowski, Tomasz Hryniewiecki, Mariusz Kuśmierczyk, Piotr Szymański \\ Department of Acquired Cardiac Defects, Institute of Cardiology, Warsaw, Poland
}

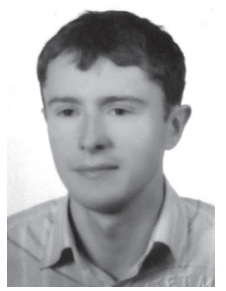

Kardiochir Torakochir Pol 2019; 16 (3): 114-117

\begin{abstract}
Aim: The aim of the study was to assess the usefulness of lactate blood levels in the perioperative period in patients undergoing heart valve surgery.

Material and methods: A prospective study was conducted on a group of consecutive patients with significant valvular heart disease who underwent elective valve surgery. The primary endpoint was total mortality in a 30-day follow-up. Univariate analysis, followed by multivariate regression analysis, was performed.

Results: The study included 801 patients. The primary end point occurred in 36 patients. At multivariate analysis lactate blood level measured one day after surgery and $\mathrm{pH}$ measured one day after surgery remained independent predictors of the primary end-point.

Conclusions: Elevated postoperative lactate blood level was associated with a higher risk of postoperative death.
\end{abstract}

Key words: lactate, risk stratification, valve surgery, postoperative strategy.

\section{Introduction}

Heart valve surgery is associated with the risk of serious postoperative complications including death. One of the main causes of death in patients undergoing heart surgery is multiple organ dysfunction syndrome (MODS) due to irreversible perioperative cell damage [1, 2]. Glycolysis is the basic energetic process occurring in the cytoplasm of cells, including the brain, heart or skeletal muscle resulting in pyruvic acid. Under aerobic conditions, pyruvate passes into the mitochondrion, where oxidative phosphorylation and the Krebs cycle allow generation of 36 moles of ATP. However, if the cells do receive a sufficient oxygen supply, their only source of energy is the energy-saving process of anaerobic glycolysis, whereby pyruvic acid with lactate dehydrogenase ( $\mathrm{LDH})$ is converted to lactic acid, which at the physiological $\mathrm{pH}$ of the blood dissociates to the anionic base (lactate) and proton $\left(\mathrm{H}^{+}\right)[3]$.

\section{Streszczenie}

Cel: Celem pracy była ocena wartości prognostycznych okołooperacyjnych poziomów mleczanów we krwi u pacjentów poddawanych operacjom zastawek serca.

Materiał i metody: Prospektywne badanie przeprowadzone na grupie kolejnych pacjentów z istotną hemodynamicznie objawową wadą zastawkową serca poddawanych leczeniu chirurgicznemu - wymianie lub naprawie zastawki. Głównym punktem końcowym w obserwacji 30-dniowej było wystąpienie zgonu z wszystkich przyczyn.

Wyniki: Badaniem objęto 801 pacjentów. Pierwszorzędowy punkt końcowy wystąpił u 36 pacjentów. W wykonanej analizie wieloczynnikowej poziom mleczanów we krwi oraz wartość pH oznaczane jedną dobę po operacji zastawkowej serca były niezależnymi predyktorami wystąpienia głównego punktu końcowego.

Wnioski: Podwyższony poziom mleczanów we krwi po operacji był związany z wyższym ryzykiem zgonu pooperacyjnego.

Słowa kluczowe: stężenie mleczanów, stratyfikacja ryzyka, operacja wady zastawkowej, strategia pooperacyjna.

The correct concentration of bicarbonate ions, which are part of the body's main buffer system (bicarbonate carbonic acid), guarantees that there is no accumulation of hydrogen ions. However, if they are depleted and/or lactic acid is produced in excess and there are disturbances of its transformation or excretion, accumulating hydrogen ions cause a decrease in $\mathrm{pH}$ and development of lactic acidosis [4-6]. The usefulness of the lactate blood levels determined in the perioperative period as a predictor of death from all causes in patients undergoing heart valve surgery has not been fully explained.

\section{Aim}

Therefore, we attempted to evaluate the prognostic value of perioperative lactate blood levels during a 30-day follow-up for death in this group of patients.

Address for correspondence: Piotr Duchnowski MD, PhD, Department of Acquired Cardiac Defects, Institute of Cardiology, 42 Alpejska St, 04-628 Warsaw, Poland, e-mail: duchnowski@vp.pl

Received: 9.07.2019, accepted: 30.08.2019. 


\section{Material and methods}

This is a prospective study of consecutive patients with hemodynamically significant valvular heart disease (aortic stenosis, aortic regurgitation, mitral stenosis, mitral regurgitation) who were approved for cardiac surgery and subsequently underwent elective replacement or repair of the valve/valves, with or without additional procedures at the Institute of Cardiology, Warsaw, Poland. The exclusion criteria were: patients under 18 years of age, a lack of consent to participate in the study, porcelain aorta, active infective endocarditis and active neoplastic diseases. The day before surgery, immediately after the patient's arrival at the intensive care clinic after surgery, 6 hours after the operation and one day after the operation (18 hours after the operation) a blood sample was collected from each patient. Complete blood count was performed with K2-EDTA samples, using a Cobas 6000 electronic counter (Roche, Mannheim, Germany). The plasma levels of lactate concentrations were measured by an electronic counter: the Cobas b 221 system (Roche, Mannheim, Germany). All procedures were performed through a midline sternotomy incision under general anaesthesia in normothermia. All patients were given cold blood cardioplegia at the initial dose of $15-20 \mathrm{ml} / \mathrm{kg}$ followed by booster doses of $5-10 \mathrm{ml} / \mathrm{kg}$ every 20 minutes. The primary end-point at the 30-day follow-up was death from all causes. Patients were followed by direct observation during hospitalization, clinic visits or telephone interview for 30 days after the surgery or until death. The protocol was approved by the Institutional Ethics Committee.

\section{Statistical analysis}

Statistical analysis was performed using SAS version 9.2 software. The Shapiro-Wilk test of normality was used to test the sample distribution. Data are presented as the mean \pm SD and the frequency (\%). Intergroup comparisons were made using the Mann-Whitney $U$ test, Pearson's $\chi^{2}$ test or Student's $t$-test. The following covariates were investigated for association with the endpoint in univariate analysis: age, aortic cross-clamp time, cardiopulmonary bypass time, atrial fibrillation, body mass index, chronic obstructive airway disease, coronary artery disease, preoperative creatinine, creatinine measured one day before the operation, preoperative hemoglobin, hemoglobin measured one day before the operation, lac (lactates measured immediately after surgery), lac I (lactates measured 6 hours after the operation), lactates II (lactates measured 1 day after the operation (18 hours after operation)), $\mathrm{pH}(\mathrm{pH}$ measured immediately after surgery), $\mathrm{pH}$ I ( $\mathrm{pH}$ measured 6 hours after operation), $\mathrm{pH}$ II (pH measured one day after the operation (18 hours after the operation)), hypertension, left ventricular ejection fraction (LVEF), New York Heart Association (NYHA) classes, platelets, pulmonary blood pressure, tricuspid annulus plane systolic excursion (TAPSE) and white blood cell count. Significant determinants $(p<0.05)$ identified from univariate analysis were subsequently entered into multivariate models. Spearman's rank correlation coefficient was used to search for associations between the postoperative serum lactates level and selected variables. Predictive value of lactates was assessed by a comparison of the areas under the receiver operator characteristics of the respective curve. On the basis of the Youden index, a cut-off point was determined that met the criterion of maximum sensitivity and specificity for mortality prediction.

\section{Results}

The study included 801 patients who underwent heart valve surgery with or without concomitant procedures. The mean age in the study group was $64.5 \pm 12.5$. Thirty-three (4.3\%) patients had significantly impaired left ventricular systolic function (ejection fraction $\leq 35 \%$ ). The mean lac blood level was $1.7 \mathrm{mmol} / \mathrm{l}$ (standard deviation (SD) \pm 0.4 ), lac I blood level was $2.2 \pm 1 \mathrm{mmol} / \mathrm{l}$ and lac I| blood level was $2.6 \pm 2 \mathrm{mmol} / \mathrm{l}$. Table I shows the characteristics of the patients studied. The primary end-point occurred in 36 patients. Total mortality was $4.4 \%$ versus $3.8 \%$ expected mortality calculated using EuroSCORE II. The first patient died suddenly (cause of death unknown) and 35 patients died during the follow-up period as a result of gradually increasing multi-organ failure. The statistically significant predictors of primary end point at univariate analysis are presented in Table II. At multivariate analysis lac II (OR = 1.413; 95\% Cl: $1.110-1.798 ; p=0.004)$ and $p H ~ I I ~(O R=1.552$ 95\% Cl: $1.146-2.102 ; p=0.009)$ remained independent predictors of the primary end-point. The optimal cut-off point for death from all causes was calculated at $3.5 \mathrm{mmol} / \mathrm{l} \mathrm{lac} \mathrm{II.}$ The area under the receiver operator characteristic curve for primary end-point for lac II is $0.805(95 \% \mathrm{Cl}$ : 0.721-0.870) (sensitivity: 75\%; specificity: 82\%) (Figure 1). A moderate correlation was found between the lac II blood level and preoperative hemoglobin $(r=-0.31 ; p=0.01)$, preoperative creatinine $(r=0.33 ; p=0.002)$, preoperative RDW $(r=0.27 ; p=0.04)$ and age $(r=0.21 ; p=0.01)$, and also between lac I blood level and preoperative hemoglobin $(r=-0.22 ; p=0.02)$ as well as preoperative RDW ( $r=0.17 ; p=0.04)$. No correlation was found between the level of lac II and postoperative hemoglobin $(p=0.2)$, aortic cross-clamp time $(p=0.12)$ or cardiopulmonary bypass time $(p=0.15)$.

\section{Discussion}

The main cause of death in the early post-operative period in patients undergoing heart valve surgery is multiple organ dysfunction syndrome (MODS) [7, 8]. The pathophysiological basis for postoperative MODS is cellular damage, which is manifested when cellular repair does not occur. During operations the oxygen consumption is inadequate to meet intraoperative metabolic requirements $[1,2,9,10]$. Hypoxia may result from insufficient blood supply caused by decreased cardiac output, reduced hemoglobin levels, or impaired absorption of oxygen by target cells. Determination of lactate blood level is helpful in diagnosis and assessment of hypoxia and lactic acidosis in people in shock or heart failure $[11,12]$. In the present study, the authors assessed the usefulness of lactate concentration in succes- 
Table I. Baseline characteristics of study population

\begin{tabular}{|c|c|}
\hline Parameter & Values \\
\hline \multicolumn{2}{|l|}{ Preoperative characteristics of patients ( $n=801)$ : } \\
\hline Age [years] $^{*}$ & $63.1 \pm 12.9$ \\
\hline Male: men, $n(\%)$ & $461(57)$ \\
\hline Body mass index $\left[\mathrm{kg} / \mathrm{m}^{2}\right]^{*}$ & $27.3 \pm 9.1$ \\
\hline NYHA, (classes)* & $2.6 \pm 0.5$ \\
\hline LV ejection fraction (\%)* & $56 \pm 11$ \\
\hline EuroSCORE $(\%)^{*}$ & $6.2 \pm 4.8$ \\
\hline EuroSCORE II (\%)* & $3.8 \pm 3.4$ \\
\hline STS (\%)* & $3.6 \pm 3.0$ \\
\hline Atrial fibrillation $n(\%)$ & $347(43)$ \\
\hline Coronary artery disease, $n(\%)$ & $111(13)$ \\
\hline Chronic obstructive airways disease, $n$ (\%) & $52(6)$ \\
\hline Chronic kidney disease (GFR < $\left.60 \mathrm{ml} / \mathrm{min} / 1.73 \mathrm{~m}{ }^{2}\right), n(\%)$ & $245(30)$ \\
\hline Diabetes mellitus, $n$ (\%) & $133(16)$ \\
\hline Hypertension, $n(\%)$ & $510(63)$ \\
\hline Peripheral atherosclerosis, $n(\%)$ & $43(5)$ \\
\hline Creatinine $[\mathrm{mg} / \mathrm{dll}]^{*}$ & $1 \pm 0.4$ \\
\hline Hemoglobin [g/dl] $]^{*}$ & $13.5 \pm 1.5$ \\
\hline \multicolumn{2}{|l|}{ Intraoperative characteristics of patients: } \\
\hline Aortic cross-clamp time $[\mathrm{min}]^{\star}$ & $94 \pm 40$ \\
\hline${\text { Cardiopulmonary bypass time }[\mathrm{min}]^{*}}^{*}$ & $122 \pm 53$ \\
\hline \multicolumn{2}{|l|}{ Postoperative characteristics of patients: } \\
\hline Lactates $[\mathrm{mmol} / \mathrm{l}]^{*}$ & $1.7 \pm 0.4$ \\
\hline Lactates I [mmol/l] $]^{*}$ & $2.2 \pm 1$ \\
\hline Lactates II [mmol//] ${ }^{*}$ & $2.6 \pm 2$ \\
\hline $\mathrm{pH}^{*}$ & $7.4 \pm 0.07$ \\
\hline $\mathrm{pH} \mathrm{I}^{*}$ & $7.32 \pm 0.2$ \\
\hline $\mathrm{pH} \mathrm{II}$ & $7.34 \pm 0.1$ \\
\hline Creatinine II [mg/dl] ${ }^{*}$ & $1.3 \pm 0.4$ \\
\hline Hemoglobin II [g/dl] ${ }^{*}$ & $10.4 \pm 1.4$ \\
\hline \multicolumn{2}{|l|}{ Main procedures: } \\
\hline AVR, $n(\%)$ & $401(50)$ \\
\hline AVP, $n(\%)$ & $30(2.6)$ \\
\hline MVR, $n(\%)$ & $161(19.7)$ \\
\hline$\overline{M V R}+\mathrm{AVR}, n(\%)$ & $60(8.4)$ \\
\hline MVP, $n(\%)$ & $149(14.6)$ \\
\hline \multicolumn{2}{|l|}{ Concomitant procedures: } \\
\hline CABG, $n(\%)$ & $110(13)$ \\
\hline
\end{tabular}

Values are represented as the mean *and a measure of the variation of the internal standard deviation. AVP - aortic valve plasty, AVR - aortic valve replacement, MVP - mitral valve plasty, MVR - mitral valve replacement, GFR - glomerular filtration rate, LV - left ventricle, NYHA - New York Heart Association. Creatinine - creatinine measured one day before operation, Creatinine II - creatinine measured one day after operation (18 hours after operation), Hemoglobin - hemoglobin measured one day before operation, Hemoglobin II - hemoglobin measured one day after operation (18 hours after operation), Lactates - lactates measured immediately after operation, $\mathrm{pH}$ $\mathrm{pH}$ measured immediately after operation, Lactates I - lactates measured 6 hours after operation, $\mathrm{pH} \mathrm{I-pH}$ measured 6 hours after operation, Lactates II - lactates measured one day after operation (18 hours after operation), $\mathrm{pH}$ II - pH measured 1 day after operation (18 hours after operation).
Table II. Univariate analysis of predictive factors for occurrence of death

\begin{tabular}{lccc} 
Variable & Odds ratio & $95 \% \mathrm{Cl}$ & $P$-value \\
Age [years] & 1.085 & $1.047-1.125$ & $<0.0001$ \\
\hline Lac I [mmol/l] & 2.001 & $1.427-2.803$ & $<0.001$ \\
\hline Lac II [mmol/l] & 1.813 & $1.377-3.389$ & $<0.0001$ \\
\hline $\mathrm{pH} \mathrm{II}$ & 1.130 & $1.053-1.186$ & $<0.0001$ \\
\hline Hemoglobin [g/dl] & 0.569 & $0.469-0.690$ & $<0.0001$ \\
\hline LV ejection fraction, \% & 0.972 & $0.951-0.993$ & 0.01 \\
\hline
\end{tabular}

Hemoglobin - hemoglobin measured 1 day before operation, Hemoglobin II - hemoglobin measured 1 day after operation (18 hours after operation), Lac I lactates measured 6 hours after operation, Lac II - lactates measured 1 day after operation (18 hours after operation), $\mathrm{pH} \mathrm{II} \mathrm{-} \mathrm{pH} \mathrm{measured} 1$ day after operation (18 hours after operation).

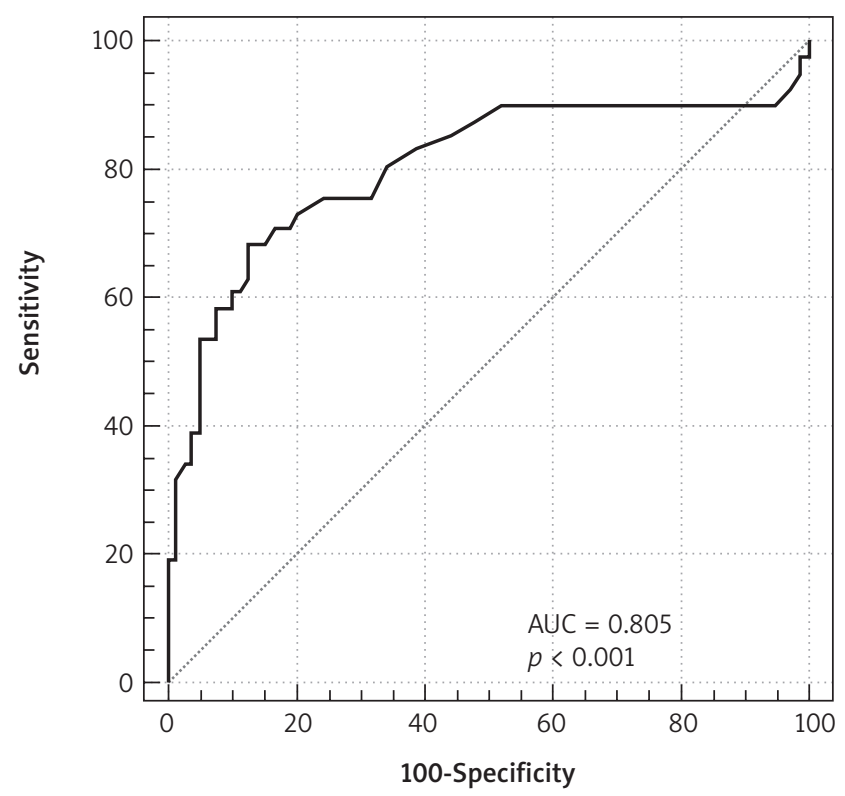

Figure 1. Area under receiver operating characteristic (ROC) curve of lactate blood level measured one day after surgery for death following valve replacement/repair surgery

sive perioperative measurements in terms of their predictive mortality in a 30-day follow-up. Under conditions of oxygen deprivation, anaerobic glycolysis is the only possible way to generate energy for the cell. In order to recover $\mathrm{NAD}^{+}$, the hydrogen atom is transferred from $\mathrm{NADH}$ to the pyruvic acid molecule to form a lactic acid molecule that dissociates to the anionic base (lactate) and proton $\left(\mathrm{H}^{+}\right)$at the physiological $\mathrm{pH}$ of the blood. So far, predictive ability of the lactate blood level was reported in patients requiring intensive therapy, especially in septic shock, with acute myocardial infarction, after liver transplantation or with bowel ischemia [13-21]. In turn, D'Arrigo et al. showed that lower lactate values were a predictor of a better prognosis after in-hospital cardiac arrest treated with extracorporeal cardiopulmonary resuscitation [22]. Moreover, Duval et al. suggest that changes in intraoperative blood lactate level $(\Delta$ Lact) are associated with poor short-term outcomes in adult patients undergoing on-pump cardiac surgery [23]. 
On the other hand, O'Connor et al. proved that the discovery of late-onset hyperlactatemia should not delay the postoperative progress of cardiac surgery [11].

In the present study, among the three lactate blood levels evaluated, only the lactate blood level measured one day after the operation was an independent predictor of death in a 30-day follow-up. It is worth noting that in 35 cases out of all 36 deaths the cause of the primary endpoint was the increasing multi-organ failure. In the current literature, it has been shown that parameters of the red blood cell system such as erythrocytes and hemoglobin (which are indicative of the possibility of oxygen transport to tissues) or RDW (described as an indicator of the patient's physiologic reserve) are independent predictors of death in patients undergoing heart surgery [24-29]. The significant correlation between lactate blood levels and preoperative parameters of the red blood cell system such as RDW or Hgb, demonstrated in this study, confirms the important role of perioperative tissue hypoxia in the development of postoperative complications.

\section{Conclusions}

In the present study lactate blood level measured one day after the operation was an independent predictor of death in a 30-day follow-up. The significant correlation between lactate blood levels and preoperative parameters of the red blood cell system confirms the important role of perioperative tissue hypoxia in the development of postoperative complications. The results of our research may be helpful in the perioperative strategy in patients undergoing heart valve surgery.

\section{Disclosure}

The authors report no conflict of interest.

\section{References}

1. Waxman K. Hemodynamic and metabolic changes during and following operation. Crit Care Clin 1987; 3: 241-250.

2. Waxman K. Postoperative multiple organ failure. Crit Care Clin 1987; 3: 429-440.

3. Minton J, Sidebotham DA. Hyperlactatemia and cardiac surgery. J Extra Corpor Technol 2017; 49: 7-15.

4. Madias NE. Lactic acidosis. Kidney Int 1986; 29: 752-774.

5. Allen SE, Holm JL. Lactate: physiology and clinical utility. J Vet Emerg Crit Care 2008; 18: 123-132.

6. Bellomo R. Bench to bed side review: lactate and the kidney. Crit Care 2002; 6: 322-326.

7. Duchnowski P, Hryniewiecki T, Kuśmierczyk M, Szymański P. The usefulness of selected biomarkers in patients with valve disease. Biomark Med 2018; 12: $1341-1346$

8. Duchnowski P, Hryniewiecki T, Koźma M, Mariusz K, Piotr S. High-sensitivity troponin $T$ is a prognostic marker of hemodynamic instability in patients undergoing valve surgery. Biomark Med 2018; 12: 1303-1309.

9. Yuan X, Lee J, Bowser J, Neudecker V, Sridhar S, Eltzschig HK. Targeting hypoxia signaling for perioperative organ injury. Anesth Analg 2018; 126: 308-321.

10. Duchnowski P, Hryniewiecki T, Kuśmierczyk M, Szymanski P. Red cell distribution width as a predictor multiple organ dysfunction syndrome in patients undergoing heart valve surgery. Biol Open 2018; 7: pii: bio.036251.
11. O'Connor E, Fraser JF. The interpretation of perioperative lactate abnormali ties in patients undergoing cardiac surgery. Anaesth Intensive Care 2012; 40: 598-603.

12. Ezekowitz JA, McAlister FA, Armstrong PW. Anemia is common in heart failure and is associated with poor outcomes: insight from a cohort of 12065 patients with new-onset heart failure. Circulation 2003; 107: 223-225.

13. Shapiro NI, Howell MD, Talmor D, Nathanson LA, Lisbon A, Wolfe RE, Weiss JW. Serum lactate as a predictor of mortality in emergency department patients with infection. Ann Emerg Med 2005; 45: 524-528.

14. Rimachi R, Bruzzi de Carvahlo F, Orellano-Jimenez C, Cotton F, Vincent JL, De Backer D. Lactate/pyruvate ratio as a marker of tissue hypoxia in circulatory and septic shock. Anaesth Intensive Care 2012; 40: 427-432.

15. Jansen TC, van Bommel J, Bakker J. Blood lactate monitoring in critically ill patients: a systematic health technology assessment. Crit Care Med 2009; 37: 2827-2839.

16. Khosravani H, Shahpori R, Stelfox HT, Kirkpatrick AW, Laupland KB. Occurrence and adverse effect on outcome of hyperlactatemia in the critically ill. Crit Care 2009; 13: R90.

17. Musikatavorn K, Thepnimitra S, Komindr A, Puttaphaisan P, Rojanasarntikul D. Venous lactate in predicting the need for intensive care unit and mortality among nonelderly sepsis patients with stable hemodynamic. Am J Emerg Med 2015; 33: 925-930.

18. Bou Chebl R, El Khuri C, Shami A, Rajha E, Faris N, Bachir R, Abou Dagher G. Serum lactate is an independent predictor of hospital mortality in critically ill patients in the emergency department: a retrospective study. Scand J Trauma Resusc Emerg Med 2017; 25: 69.

19. Gjesdal G, Braun OÖ, Smith JG, Scherstén F, Tydén P. Blood lactate is a predictor of short-term mortality in patients with myocardial infarction complicated by heart failure but without cardiogenic shock. BMC Cardiovasc Disord 2018; 18: 8.

20. Kim DG, Lee JY, Jung YB, Song SH, Lee JG, Han DH, Joo DJ, Ju MK, Choi GH, Choi JS, Kim MS, Kim SI. Clinical significance of lactate clearance for the development of early allograft dysfunction and short-term prognosis in deceased donor liver transplantation. Clin Transplant 2017; 31: doi: 10.1111/ ctr.13136.

21. Sekino M, Funaoka H, Sato S, Okada K, Inoue H, Yano R, Matsumoto S, Ichinomiya T, Higashijima U, Matsumoto S, Hara T. Intestinal fatty acid-binding protein level as a predictor of 28-day mortality and bowel ischemia in patients with septic shock: a preliminary study. J Crit Care 2017; 42: 92-100.

22. D’Arrigo S, Cacciola S, Dennis M, Jung C, Kagawa E, Antonelli M, Sandroni C. Predictors of favourable outcome after in-hospital cardiac arrest treated with extracorporeal cardiopulmonary resuscitation: a systematic review and meta-analysis. Resuscitation 2017; 121: 62-70.

23. Duval B, Besnard T, Mion S, Leuillet S, Jecker O, Labrousse L, Rémy A, Zaouter C, Ouattara A. Intraoperative changes in blood lactate levels are associated with worse short-term outcomes after cardiac surgery with cardiopulmonary bypass. Perfusion 2019 Jun 28. doi: 10.1177/0267659119855857.

24. Bion JF. Susceptibility to critical illness: reserve, response and therapy. Intens Care Med 2000; 26: 57-63.

25. Miceli A, Romeo F, Glauber M, de Siena PM, Caputo M, Angelini GD. Preoperative anemia increases mortality and postoperative morbidity after cardiac surgery. J Cardiothorac Surg 2014; 9: 137.

26. Cladellas M, Bruguera J, Comin J, Vila J, de Jaime E, Marti J, Gomez M. Is preoperative anaemia a risk marker for in-hospital mortality and morbidity after valve replacement? Eur Heart J 2006; 27: 1093-1099.

27. Duchnowski P, Hryniewiecki T, Stokłosa P, Kuśmierczyk M, Szymański P. Number of erythrocytes as a prognostic marker in patients undergoing heart valve surgery. Kardiol Pol 2018; 76: 791-793.

28. Duchnowski P, Hryniewiecki T, Kuśmierczyk M, Szymański P. The usefulness of selected biomarkers in aortic regurgitation. Cardiol J 2018 Sep 20. doi: 10.5603/CJ.a2018.0108. [Epub ahead of print]

29. Elmistekawy E, Rubens F, Hudson C, McDonald B, Ruel M, Lam K, Mesana TG, Boodhwani M. Preoperative anaemia is a risk factor for mortality and morbidity following aortic valve surgery. Eur J Cardiothorac Surg 2013; 44: 1051-1055. 